\title{
Meningkatkan Kualitas Proses dan Hasil Pembelajaran Tentang Gaya Lorentz Melalui Pembelajaran Kooperatif Tipe STAD
}

\author{
Yohana Prisuharti
}

SMA Negeri 3 Pontianak, Dinas Pendidikan Kota Pontianak

\begin{abstract}
Abstrak
Tujuan penelitian tindakan kelas ini untuk meningkatkan kualitas proses dan hasil belajar siswa tentang Gaya Lorentz melalui pembelajaran kooperatif tipe STAD. di SMAN 3 Pontianak terhadap 40 siswa kelas XII IPA. Penelitian berlangsung dalam 3 siklus. Sasaran penelitian difokuskan pada pemahaman konsep dan pemecahan masalah Gaya Lorentz. Tingkat keberhasilan tercapai apabila minimal 70\% siswa memperoleh nilai di atas 65.Pengumpulan data dilakukan dengan melakukan pretest dan postest pada akhir siklus. Test pemahaman konsep dan pemecahan masalah dilakukan dalam bentuk uraian terstruktur, Hasil penelitian menunjukkan peningkatan kualitas pembelajaran siswa dalam pemahaman konsep dan kemampuan memecahkan masalah.Dari hasil analisis terjadi kenaikan nilai yang sangat signifikan pada tiap siklus. Berarti melalui pembelajaran kooperatif, kualitas proses dan hasil belajar menjadi lebih baik, karena siswa menjadi lebih aktif untuk mengikuti kegiatan pembelajaran
\end{abstract}

Kata kunci: kualitas proses dan hasil, pembelajaran kooperatif tipe STAD

\section{Pendahuluan}

Pelajaran fisika merupakan mata pelajaran IPA yang dianggap sulit oleh sebagian siswa sejak mereka masih di SLTP sampai mereka ditingkat SMA.Hal ini disebabkan karena pembelajaran Fisika berisi konsep-konsep ataupun teori-teori yang bersifat abstrak, faktafakta serta pengalaman langsung yang dapat diperoleh melalui laboratorium atau pengalaman sehari-hari di lingkungannya, Selain itu kesulitan yang dialami siswa adalah mengubah kalimat fisika menjadi kalimat matematika serta banyaknya rumus yang harus dihafal.

Pembelajaran IPA cenderung disajikan dengan cara konvensional, dimana guru mendominasi kegiatan pembelajaran dan siswa hanya sebagai pendengar dan mencatat semua yang diucapkan guru (Ali, 1984,3). Akibatnya menghambat peran aktif siswa dalam mencari dan menemukan sendiri pengetahuan, keterampilan sikap yang diperlukan dalam kegiatan pembe-lajaran.

Menurut Weill (dalam Depdikbud 1997), pembelajaran harus lebih menitikberatkan pada aktivitas belajar siswa dalam mencapai kompetensi sesuai dengan tujuan pembelajaran fisika dalam Kurikulum Tingkat Satuan Pendidikan (KTSP). Melalui pelajaran sains, fokus (mumpun) dan tekanan (emphasis) terletak pada bagaimana guru membiarkan siswa dapat bersikap jujur dan tak berprasangka. Dari pengalaman memecahkan persoalan fisika, siswa dilatih untuk gigih dan tekun menghadapi kesulitan. (Wilardjo ,2003:51) Siswa diharapkan memiliki pengalaman belajar dengan kerja ilmiah, mampu untuk bernalar, mampu menerapkan konsep fisika dalam bidang teknologi maupun dalam kehidupan sehari-hari. sehingga siswa mampu menyesuaikan diri dengan perkembangan ilmu pengetahuan dan lingkungan. 
Menurut Driver dan Bell (Suparno,1997:17), ilmu pengetahuan terutama sains adalah ciptaan pikiran manusia dengan semua gagasan dan konsep yang ditemukan secara bebas. Menurut Einstein dan Infeld (Suparno, 1997:17 ) konsep dan teori tidak menurut pengamat-an induktif yang sederhana. Hal ini dapat dilihat dari ketidakmampuan siswa meng-abstraksi kan kenyataan yang diperoleh dengan percobaan yang dilakukan. Menurut Cross ( Rohandi, 2003, 117) Sains sangat memegang peranan penting dalam mengubah siswa menjadi berdaya (empowered), hal ini ditandai dengan sikap untuk lebih memelihara, kompetitif, saling menolong dalam situasi yang heterogen.

Menurut Whiteheat (Sumaji, 2003:31) Sains dibentuk karena pertemuan 2 orde pengalaman yaitu didasarkan pada hasil observasi terhadap gejala atau fakta (orde observasi) dan didasarkan pada konsep manusia mengenai alam semesta (orde konsepsional). Sains membangkitkan minat manusia untuk meningkatkan kecerdasan, pemahaman tentang alam dan seisinya. Fisika berkembang seiring dengan perkembangan teknologi, sehingga fisika merupakan tulang punggung teknologi modern. Contohnya teknologi komunikasi, transportasi, elektronika dan informasi (Depdiknas ,2002:6). Dengan menguasai fisika diharapkan sumber daya manusia yang akan datang akan lebih maju dan dapat bersaing dengan bangsa-bangsa lain. Makin banyaknya segi kehidupan dipengaruhi hasil-hasil sains, sehingga sains merupakan bagian budaya dan bagian hidup dari suatu bangsa (Winataputra,1997:130).

Gaya Lorentz merupakan salah satu materi dalam pembelajaran fisika yang mempelajari gaya pada penghantar berarus yang berada di dalam medan magnet (Kanginan, 2000) dan merupakan prasarat dalam pembelajaran Induksi elektromagnetik serta sangat esensial karena sering muncul pada EBTANAS. Dalam mempelajari Gaya Lorentz siswa harus memahami konsep medan magnet dan cara menentukan arah medan magnet disekitar penghantar berarus. Kesulitan yang sering dihadapi siswa adalah cara menentukan arah gaya dengan menggunakan aturan tangan kanan dan hitung-an vektor dalam memecahkan masalah. Untuk meningkatkan pemahaman siswa akan Gaya Lorentz, pembelajaran perlu diubah dari cara konvensional menjadi cara pendekatan kooperatif.

Penelitian pendidikan sains menunjukkan suatu pergeseran ke arah paradigma konstruktivis. Artinya seseorang belajar tidak hanya meniru yang diajarkan atau yang dibaca melainkan menciptakan pengertian (Suparno,1997:11). Pengetahuan dan pengertian dibentuk siswa secara aktif dan bukan diterima secara pasif dari guru.

Permasalahan yang dihadapi memberikan inspirasi untuk merancang suatu pendekatan pembelajaran yang menarik,membuat siswa merasa senang untuk belajar dan lebih mudah memahami materi yang diajarkan. Menurut Dryden dan Vos (1999) rasa senang dalam belajar merupakan kunci sukses dalam menguasai pelajaran. Pendekatan pembelajaran yang diguna-kan adalah pendekatan kooperatif dengan tipe STAD, pendekatan konstruktivis dalam pengajaran fisika dapat dilakukan dengan cara kooperatif. Pembelajaran kooperatif turut menambah unsur-unsur interaksi sosial dalam pembelajaran dengan cara bekerja sama menuntaskan materi belajarnya. Pendekatan kooperatif tipe STAD merupakan relevansi dari teori konstruktivis dimana siswa secara aktif mengembangkan dan membangun kemampuannya sendiri. Melalui pembelajaran ini diharapkan dapat meningkatkan kemampuan akademik, meningkatkan kemampuan bersosialisasi dan berkolaborasi serta melatih 
kemampuan untuk mene-rima keragaman atau perbedaan.

Menurut Glasersfeld (1996), dalam proses konstruksi diperlukan kemampuan sebagai berikut: kemampuan mengingat dan mengungkapkan kembali pengalaman, kemampuan membandingkan, mengambil keputusan (justifikasi) mengenai persamaan dan perbedaan.dan kemampuan untuk lebih menyukai pengalaman yang satu dari pada yang lain.

Pembelajaran

kooperatif merupakan strategi belajar dengan jumlah kelompok yang kecil dan tingkat kemampuan yang berbeda untuk mencapai ketrampilan individu melalui kerja sama.. Kelebihan pembelajaran kooperatif menurut Slavin (1991) adalah meningkatkan pencapaian dan kemahiran kognitif bagi siswa dengan kemampuan akademis rendah maupun bagi siswa dengan kemampuan akademik lebih atas. (Ibrahim ,2000:9). Menurut Vygotsky fungsi mental yang lebih tinggi muncul dalam percakapan atau kerjasama antar individu sebelum fungsi mental yang lebih tinggi terserap oleh individu tersebut (Sudibyo, dalam Djudin 2006).

Rumusan masalah yang perlu untuk dilakukan pemecahannya melalui peneli tian tindakan kelas adalah "Apakah pembelajaran melalui pendekatan kooperatif tipe STAD pada Gaya Lorentz dapat meningkatkan kualitas proses dan hasil belajar siswa di kelas XII IPA?" Pendekatan pembelajaran kooperatif tipe STAD bertujuan melibatkan siswa secara berkelompok untuk memecahkan masalah dan meningkatkan proses pem belajaran sehingga tercapai kompetensi yang diharapkan. Sehubungan dengan itu, alter-natif tindakan yang dilakukan adalah:

1. Melakukan pretest untuk menge tahui profil kompetensi awal siswa mengenai medan magnet induksi dan Gaya Lorentz

2. Melakukan pembentukan konsep dengan demonstrasi yang dapat meng giring siswa untuk mengkonstruksikan pengetahuannya melalui diskusi kelompok.

3. Melakukan peningkatan terhadap proses pembelajaran dengan menggunakan lembaran observasi aktivitas siswa dan guru.

4. Melaksanakan tes disetiap akhir siklus. Pembelajaran. dikatakan berhasil apabila 70\% dari keseluruhan siswa mencapai KKM dengan nilai minimal 65 .

Tujuan umum penelitian adalah untuk meningkatkan kualitas proses dan hasil belajar siswa kelas XII IPA pada pembelajaran Gaya Lorentz melalui pendekatan kooperatif tipe STAD.

\section{Metode Penelitian}

Penelitian dilakukan di SMAN 3 Pontianak dengan subjek penelitian siswa XII IPA. Jumlah siswa 40 orang, terdiri dari 14 siswa laki-laki dan 26 siswa perempuan. Kemampuan siswa kelas ini relatif lebih baik daripada kelas paralelnya serta sangat heterogen. Pelaksanaan penelitian dilakukan pada semester ganjil dengan materi Gaya Lorentz dan dilakukan sesuai dengan jadwal mengajar guru.

Prosedur penelitian yang dilakukan meliputi :

a. Perencanaan tindakan meliputi penyusunan skenario pembelajaran/RPP dengan model kooperatif dan menyusun pretest, LKS dan postest.

b. Melakukan tindakan dengan menggunakan pendekatan kooperatif .

c. Observasi yang dilakukan oleh pembimbing melalui lembar observasi

d. Refleksi yang dilakukan teman sejawat dan pembimbing.

Tujuan penelitian untuk memecahkan banyak masalah praktis dan memperbaiki kualitas pembelajaran pada 
materi Gaya Lorentz. Penelitian berlangsung pada 4 tahap yaitu tahap perencanaan, pelaksanaan, observasi dan refleksi dan dilakukan dalam 3 siklus. Pembagian siklus mengacu pada indikator pencapaian kompetensi yang terdapat pada kurikulum Fisika SMA.

Sasaran pembelajaran yang ingin dicapai dalam tiap siklus adalah:

1. Siklus I berisi pemahaman konsep dan pemecahan masalah medan magnet

2. Siklus II memfokuskan pada pemahaman tentang Gaya Lorentz.

3. Siklus III memfokuskan pada pemecahan masalah Gaya Lorentz.

Pada setiap akhir siklus dilakukan tes. Tingkat keberhasilan pada tiap siklus tercapai jika $70 \%$ siswa mencapai nilai minimal 65. Apabila kriteria yang ditetapkan tidak tercapai, maka dilakukan per-baikan sebelum melanjutkan ke siklus berikut.

\section{Hasil dan Pembahasan}

Kegiatan pra tindakan diawali wawancara dengan pembimbing dan observer tentang materi yang akan diteliti. Diskusi tersebut dilakukan untuk mengetahui permasalahan-permasalahan yang dihadapi siswa di kelas XII IPA tentang Gaya Lorentz. Observasi awal dilakukan dalam bentuk pretest untuk mengetahui diskripsi konsepsi awal siswa tentang Soal pretest terdiri dari 6 soal konsep medan magnet, 4 soal konsep gaya lorentz dan 4 soal pemecahan masalah medan magnet dan gaya Lorentz. Sebelum pelaksanaan pretest siswa diminta untuk membaca buku pegangan siswa. Nilai maksimum yang dapat dicapai siswa 100. Dari analisa hasil pretes, tidak ada siswa yang mencapai nilai KKM. Pada test pemahaman konsep medan magnet nilai rata-rata kelas 56,32, pada soal konsep gaya lorentz rata-rata kelas 36,18 dan pada soal pemecahan masalah rata-rata kelas 16,3. Kesulitan dialami siswa pada cara menentukan arah medan magnet induksi, menentukan arah Gaya Lorentz serta kesulitan menjawab soal pemecahan masalah. Melalui wawan-cara dengan siswa, mereka berkeinginan untuk melihat adanya medan magnet dan Gaya Lorentz. Setelah melakukan diskusi dengan teman sejawat dan pembimbing maka proses pembelajaran yang sesui untuk mempelajari materi gaya Lorentz dilakukan melalui pendekatan pembelajar-an kooperatif tipe STAD.

Kegiatan pembelajaran dilakukan dengan menggunakan 3 siklus.

\section{Siklus Pertama.}

Pembelajaran ditujukan pada pemahaman konsep Medan Magnet Induksi disekitar kawat lurus, kawat melingkar dan kumparan. Pembelajaran dilakukan melalui pendekatan langsung menggu-nakan soal latihan pemahaman konsep Medan Magnet Induksi. Pelajaran dimulai dengan memotivasi siswa dengan cara mendekatkan magnet jarum di sekitar kawat lurus berarus listrik. Siswa mengamati peristiwa yang terjad pada magnet jarum tersebut. Kemudian membalik arah baterai, siswa dapat mengamati perubahan arah gerak jarum. Setelah itu magnet jarum digerakkan mendekati dan menjauhi kawat siswa dapat menyebutkan peristiwa yang terjadi. Melalui pengamatan yang dilakukan siswa dapat memahami konsep adanya medan magnet induksi sekitar penghan-tar berarus listrik. Dari hasil pengamat-an, kelomok siswa diminta untuk me-nentukan sendiri arah medan magnit di suatu titik disekitar kawat lurus berarus dengan menggunakan gambar yang disedia-kan pada LKS. Setelah siswa memahami cara menentukan medan magnet induksi akibat kawat lurus berarus listrik, kegiatan dilanjutkan dengan menentukan arah medan magnet induksi pada kawat melingkar dan kum-paran berarus dengan bimbingan guru. 
Pemahaman siswa dilanjutkan dengan menentukan arah medan magnet pada kawat lurus berarus yang diletakkan di dalam ruang. Dengan melakukan diskusi siswa dapat menentukan kearah sumbu mana nedan magnet induksi yang dihasilkan. Pertemuan berikutnya siswa dibimbing untuk menentukan rumus kuat medan magnet induksi pada kawat lurus berarus, kawat melingkar dan kumparan untuk dapat memecahkan masalah yang berhubungan dengan medan magnet induksi sesuai dengan RPP dan LKS yang sudah dirancang yaitu berupa soal yang berhubungan dengan konsep maupun soal pemecahan masalah. Selesai diskusi perwakilan kelompok memaparkan hasil diskusi ke depan kelas. Kelompok lain dapat memberikan pendapat dan mengajukan pertanyaan.

Hasil observasi yang dila kukan diperoleh:

1. Pada saat memotivasi siswa melalui demontrasi siswa dapat memahami bahwa makin jauh letak magnet dari kawat maka makin kecil simpangan magnet jarum dan bila arah arus listrik dibalik, arah gerak magnet jarum juga terbalik.

2. Dalam diskusi pemahaman konsep dan pemecahan masalah siswa sangat aktif dan bersemangat terutama dalam menentukan arah medan magnet induksi.

3. Diskusi kelompok berlangsung sangat aktif, tetapi beberapa siswa masih sebagai pendengar. Hal ini dikarenakan masih adanya rasa kurang percaya diri atau rasa malu

4. Ketika wakil kelompok menyampaikan hasil diskusinya ke depan kelas, siswa lain memberikan tanggapan positif dengan mengajukan pertanyaan dan koreksi pada hasil pekerjaan kelompok lain. Guru tidak membenarkan atau menyalahkan, tetapi pada akhir diskusi guru menguatkan hasil yang telah diperoleh siswa.

Setelah kegiatan pembelajaran, dilakukan refleksi. Hasil refleksi ditemukan :

1. Masih ada 6 siswa yang kurang berani mengemukakan pendapat

2. Ada 4 siswa yang memiliki kemam puan tinggi mendominasi kelompok nya. Hal ini disebabkan karena mereka ingin cepat menyelesaikan tiap soal yang disajikan, sehingga guru perlu mengingatkan kembali pentingnya kerjasama.

3. Bimbingan guru kurang merata pada tiap kelompok, maka guru perlu mengupayakan porsi waktu bagi tiap kelompok.

Untuk mengukur pemahaman konsep dan mengukur kemampuan memecahkan masalah dilakukan test tentang pemahaman konsep dan pemecahan masalah menggunakan persamaan Kuat Medan Magnet Induksi pada penghantar berarus. Pada setiap diskusi kelompok terlihat siswa sangat bersemangat, mereka saling adu argumentasi terutama dalam menentukan arah medan magnet. Akhir diskusi guru membuat kesimpulan hasil belajar dan mendapatkan rumus kuat medan magnet induksi pada kawat lurus panjang, kawat melingkar dan kumparan.

Hasil test menunjukkan adanya peningkatan pemahaman konsep dan pemecahan masalah mengenai medan magnet induksi. Rata-rata hasil postest dari 40 siswa adalah 67,45. berarti 65\% siswa yang memenuhi KKM, atau hanya 26 siswa yang berhasil. Pertemuan dilanjutkan ke siklus 2.

\section{Siklus Kedua.}

Sebelum melanjutkan ke materi berikutnya, dilakukan pengulangan terhadap materi sebelumnya yang dirasa belum tuntas. Kegiatan inti dilakukan melalui demontrasi dan pembelajaran 
difokuskan pada pemahaman Gaya Lorentz. Pada kegiatan pembelajaran wakil siswa dari tiap kelompok mengamati melalui jarak dekat apa yang terjadi apabila 2 kawat sejajar berarus listik berada sangat dekat? Bagaimana jika jumlah baterai ditambah atau dikurangi? Panjang kawat diperpanjang atau diperpendek terhadap gerak kedua kawat demon-trasi mendorong siswa menemukan hubungan antara arus listrik yang mengalir, panjang kawat dan jarak kedua kawat terhadap simpangan kawat.

Diskusi dilanjutkan tentang cara menentukan besar Gaya Lorentz yang bekerja pada dua kawat sejajar berarus dan pada muatan yang bergerak di dalam medan magnet. Diskusi berlangsung dengan bimbingan guru untuk mendapatkan rumusan gaya Lorentz. Guru memberikan beberapa soal pemahaman konsep untuk diselesaikan siswa melalui diskusi kelompok.

Hasil diskusi yang telah dilakukan disampaikan perwakilan kelompok siswa ke depan kelas. Pembahasan tidak mengalami kesulitan, karena siswa sudah memahami cara menentukan arah medan magnet dengan menggunakan aturan tangan kanan. Kesulitan terjadi ketika menentukan arah Gaya Lorentz pada muatan positif dan muatan negatif yang bergerak di dalam Medan Magnet, sehingga guru harus membimbing siswa menjelaskan cara menentukan arah gaya dari muatan yang bergerak di dalam medan magnet.

Berdasarkan observasi pembimbing dan teman sejawat diperoleh kesimpulan bahwa diskusi yang dilakukan lebih aktif dari pada sebelumnya. Kerja sama atar anggota kelompok lebih baik terutama pada saat menentukan arah gaya lorentz menggunakan aturan tangan kanan.Pada saat demonstrasi ada satu kelompok yang memberikan simpulan berbeda dengan kelompok lain sehingga menyebabkan demonstrasi harus diulang. Demontrasi memerlukan waktu yang cukup lama sehingga siswa tidak diberikan test tetapi diberi tugas mandiri.

Hasil analisis tugas yang telah dilakukan siswa, menunjukkan adanya pe-ningkatan pemahaman konsep tentang gaya Lorentz sehingga nilai rata-rata postest menjadi 71,05 yaitu sebanyak $72,5 \%$ siswa melebihi KKM. Secara umum siswa memahani konsep Gaya Lorentz, maka pembelajaran dilanjutkan ke siklus ketiga.

\section{Siklus Ketiga}

Peningkatan kemampuan siswa dalam memecahkan masalah Gaya Lorentz pada 2 atau lebih kawat sejajar, ataupun pada muatan yang bergerak di dalam medam magnet. Guru memulai dengan memberikan motivasi pada siswa dengan contoh soal pemecahan masalah dalam kehidupan sehari-hari menggunakan persamaan/rumus yang sudah dipelajari. Kemudian memberikan beberapa soal pemecahan menggunakan LKS untuk diselesaikan melalui diskusi kelompok.

Untuk menyajikan hasil kerja kelompok, guru mengundi kelompok yang akan maju ke depan kelas untuk menyampaikan hasil diskusi masingmasing kelompok. Tujuannya agar siswa selalu siap dan mereka dapat berusaha untuk menyelesaikan pekerjaannya dengan baik. Hasil diskusi kelompok dipaparkan oleh perwakilan kelompok ke depan kelas. Secara umum siswa aktif dalam mengikuti diskusi. Setelah diskusi berakhir guru memberikan penguatan pada hasil kerja kelompok.

Test pemecahan masalah dilakukan pada hari yang sama. Berdasarkan hasil test, kualitas hasil belajar siswa mengenai Gaya Lorentz meningkat. Nilai rata-rata menjadi 78,46 atau $77.5 \%$ siswa mendapat nilai minimal 65 .

Hasil refleksi menunjukkan bahwa terjadi peningkatan proses dan hasil pembelajaran fisika, khususnya pada materi Gaya Lorentz. Berarti penelitian tindakan pembelajaran melalui 
pendekatan kooperatif tipe STAD sangat relevan. Pembelajaran kooperatif sangat relevan untuk membuat anak menjadi lebih aktif dan bersemangat. Terutama dapat meningkatkan rasa percaya diri karena dapat menyelesaikan masalah.

\section{Simpulan dan Saran \\ Simpulan}

Berdasarkan hasil analisa data dan pembahasan maka dapat dikemuka kan simpulan sebagai berikut:

1. Konsep awal mengenai medan magnet induksi dan Gaya Lorentz belum dikuasai siswa kelas XII IPA Ketika melakukan pretest nilai yang diperoleh siswa pada pemahaman konsep medan magnet adalah 56,32, pada pemahaman konsep Gaya Lorentz 36,18 dan pada pemecahan masalah Gaya Lorentz 16,3 dari nilai maksimum 100.

2. Model pembelajaran dengan pende katan kooperatif tipe STAD dapat meningkatkan proses pem-belajaran karena siswa dapat menjadi lebih aktif dalam membangun pemahaman dan kemampuan pemecahan masalah Gaya Lorentz. Melalui model pembelajaran ini motivasi siswa dalam belajar Fisika menjadi lebih tinggi.

3. Setelah dilakukan pembelajaran melalui pendekatan kooperatif tipe STAD kualitas hasil belajar siswa semakin meningkat, karena model pembelajaran ini dapat meningkatkan pamahaman dan kemampuan memehan masalah tentang Gaya Lorentz.

\section{Saran}

Berdasarkan data dan analisis data yang telah dilakukan pada kegiatan penelitian, disarankan hal berikut :

1. Pembelajaran dengan pendekatan kooperatif tipe STAD dapat meningkatkan pemahaman dan kemampuan pemecahan masalah, sehingga diharapkan guru fisika dapat mengembangkan model pembelajaran ini sebagai salah satu alternatif dalam meningkatkan pembelajarannya.

2. Pendekatan kooperatif tipe STAD dapat menjadikan siswa lebih aktif dan kreatif membangun pengetahu-annya secara bersama serta mem-buat siswa dapat menghargai pen-dapat orang lain.

\section{Daftar Pustaka}

Achmadi. (1997). Strategi Belajar Mengajar. Bandung: Pustaka Setia. Akhmad Sudrajad. Teori-teori Pokok Belajar, www. Akhmadsudrajad wordpress . com. Online, Desember 2007

Ali. M .(1984). Guru Dalam Proses Belajar Mengajar. Bandung : Sinar Baru.

Budiningsih Asri . (2004). Belajar dan

Pembelajaran . Jakarta: Rineka Cipta

Dahar M . (1989 ). Teori-teori Belajar. Bandung: Erlangga

Hasibuan dan Moedjiono. ( 2000). Proses Belajar Mengajar. Bandung: Remaja Rosdakarya

Ibrahim. M. (2000). Pembelajaran Kooperatif. Surabaya: Unesa University Press

Kanginan Marten. (2003). Fisika 2000. Jakarta: Erlangga Sanjaya Wina. (2005). Pembelajaran Dalam Implementasi Kurikulum Berbasis Kompetensi. Bandung

Sardiman A.M. (2003). Motivasi Belajar Mengajar. Jakarta: Rajawali Pers

Sumaji, dkk .(1997). Pendidikan Sains yang Humanistis. .Yogyakarta: Kanisius

Suparno Paul . (1997). Filsafat Konstruktivisme dalam Pendidikan. Yogyakarta: Kanisius

Winataputra, dkk. (1997). Strategi Belajar Mengajar IPA . Jakarta : Depdikbud 